Голікова О. С. [1; ORCID ID: 0000-0001-7301-2430], М.н.С. відділу економічного регулювання природокористування ${ }^{1} /$ нститут проблем ринку та економіко-екологічних досліджень НАН України, м. Одеса, Україна

\title{
ПРОГРАМНИЙ ПІДХІД ДО ПИТАННЯ ДИВЕРСИФІКАЦІЇ ВИКОРИСТАННЯ ПРИРОДНИХ РЕСУРСІВ У РЕКРЕАЦІЙНО-ТУРИСТИЧНІЙ СФЕРІ
}

У статті визначено передумови реалізації стратегії диверсифікації використання природних ресурсів в рекреаційно-туристичній сфері. Проаналізовано стан та характеристики соціо-економічної ситуації рекреаційного об'єкта на прикладі територій басейну Куяльницького лиману. Проведено SWOT-аналіз в контексті диверсифікації використання природних ресурсів територій басейну Куяльницького лиману. Проаналізовано динаміку економічних та наявних експлуатаційних показників підприємства рекреаційної сфери на прикладі ДП «Клінічний санаторій ім. Пирогова» ПрАТ «Укрпрофоздоровниця». Виокремлено низку проблемних питань, задля вирішення яких пропонується проєкт Програми. Наведено проєкт Програми реалізації диверсифікації використання природних ресурсів, сформовано мету, надано структуру, основні заходи. Розкрито пріоритетні напрями Програми та їх складові, надано механізми реалізації пріоритетних напрямів. Запропоновано джерела фінансування Програми, виконавців та відповідальних за функцію постійного моніторингу за виконанням програмних заходів.

Ключові слова: програма диверсифікації; природні ресурси; рекреаційно-туристична сфера; програма реалізації стратегії диверсифікації.

Постановка проблеми. Сучасні умови економічного розвитку характеризуються неефективним природокористуванням та обмеженістю природних рекреаційних ресурсів, їх вичерпанням. Комплексні, багаті на природні ресурси території є вразливими, при програмно-цільовому плануванні їх розвитку слід застосовувати диверсифікаційний підхід, який би враховував позитивний вітчизняний і зарубіжний досвід, а також узгоджував інтереси зацікавлених сторін, більш повно використовував природноресурсний потенціал і забезпечував доцільний вибір стратегічних пріоритетів і засобів їх реалізації. 
Дослідженню питання вибору та впровадження стратегій, в т.ч. диверсифікації, присвячено праці таких видатних зарубіжних вчених, як І. Ансофф, С. Беррі, Р. Грант, М. Горт, Р. Кунц, М. Портер, [16], а також висвітлено в працях вітчизняних науковців: М. Корінька, Р. Акмаєвої, С. Александрова, І.Бланк, І. Саух, Є. Сич, Г. Вартанян, Н. Хумарової та багатьох інших [7-14]. Слід зазначити на активне використання диверсифікаційних стратегій в різних секторах економіки, зокрема присвячених проблемам стратегічного управління підприємствами в рекреаційно-туристичній сфері: Н. Андрєєва, Г. Вартанян, Є. Милованов, Н. Кудла, М. Мальська, Т. Момонт, С. Нездоймінов, О. Бордун, І. Стеценко [15-22]. На думку зазначених авторів, стратегії диверсифікації в рекреаційнотуристичній сфері не може бути короткостроковою, оскільки орієнтовані на перспективу та підвищення конкурентоспроможності регіону або підриємтсва, тобто потрібно визначити та оцінити поточний стан галузі, місце на ринку рекреаційно-туристичних послуг та його переваги порівняно з іншими видами діяльності [22]. Таким чином, різноспрямованість наукових позицій щодо диверсифікації та їі використання для рекреаційно-туристичної сфери визначає актуальність теми статті, мету і завдання дослідження.

Постановка завдання. Визначення специфіки та способів використання природно-ресурсного потенціалу певної території дозволить обґрунтувати основні завдання та запропонувати проєкт програми щодо іiі диверсифікації; визначити сильні та слабкі сторони, основні завдання програми запропонувати складові та напрямки програми реалізації стратегії диверсифікації використання природних ресурсів у рекреаційно-туристичній сфері.

Основні результати дослідження. Як зазначають КривицькаН. Ю. та ГромоваА. С. [23] розробка та впровадження стратегії диверсифікації проводиться у разі наявності економічно привабливих можливостей поза основним бізнесом або якщо виникає гостра / кризова необхідність. Важливість визначення екологобезпечних заходів у роботі Костецької К., Хумарової Н., Уманської Ю., Коваля В. та ін. [24] передбачає зміну методологічного підходу В природокористуванні для створення програмностратегічних документів щодо моніторинг стану та розвитку природних ресурсів в регіоні, здоров'я населення, малого бізнесу тощо. Інклюзивне (комплексне) управління природою може сприяти регіональним економічним перетворенням, забезпечуючи при цьому оптимальне використання ресурсів для забезпечення кращої якості навколишнього середовища. Автори у своїх роботах визначають, що 
під диверсифікацією слід розуміти алгоритм рішень та дій, що направлені на диверсифікацію джерел доходів, які сприяють досягненню кінцевої мети - стійкому економічно ефективному розвитку територій, регіону або підприємств.

Багатофакторність процесів формування передумов комплексного соціо-економіко-екологічного розвитку території басейну Куяльницького лиману визначає виняткову необхідність застосування стратегічного підходу для забезпечення диверсифікації використання їі природних ресурсів. Слід зазначити, що господарська діяльність в басейні Куяльницького лиману спрямована на сільське господарство та промислове виробництво, проте необхідною $€$ диверсифікація використання природноресурсного потенціалу цієї території у напряму ведення рекреаційнотуристичної діяльності одночасно із існуючими видами виробництва. Процеси диверсифікації полягатимуть у виробництві екологічно чистої продукції та наданні послуг для більш повного задоволення потреб рекреантів і сприятимуть збільшенню попиту на них, а диверсифіковані види господарської діяльності забезпечуватимуть синергетичний ефект та підвищення економічних показників розвитку районів навколо Куяльницького лиману.

Також аргументом в актуалізації цього підходу є те, що під час створення відповідних передумов братимуть участь установи, підприємства або фізичні особи, які працюють у різних сферах економіки, різних форм власності та підпорядкування, інші стейкхолдери: санаторно-курортні установи, підприємства або фізичні особи-підприємці, які створюють косметологічну продукцію, а також салони краси із використанням ресурсного потенціалу Куяльницького лиману (ропи, грязей, солі, блакитної глини, фітопрепаратів). 3 огляду на зазначене необхідною є розробка єдиної системи залучення та взаємодії цих суб'єктів господарювання шляхом комплексного використання природноресурсного потенціалу на основі урахування їх економічних інтересів у відповідності до інтересів самої території (жителів громад), місцевих органів самоврядування, для виробництва більшого асортименту товарів та послуг, необхідних для відпочинку, лікування та оздоровлення людей в природному середовищі з одночасним розвитком супутніх видів діяльності, що сприяють охороні та відтворенню лікувальних, оздоровчих, туристичних та інших природних ресурсів на основі інноваційної діяльності.

Вважаємо, що для екологобезпечного соціально-економічного розвитку території Куяльницького лиману та зменшення навантаження на його природні ресурси необхідно розробити та 
Серія «Економічні науки»

Випуск 4(92) 2020 p.

затвердити середньострокову регіональну програму розвитку рекреаційної зони у басейні Куяльницького лиману з урахуванням проведення диверсифікації використання природних ресурсів. Під програмою розуміється документ, який забезпечує реалізацію відповідної стратегії, що спрямована на диверсифікацію використання соціо-економіко-екологічного та природно-ресурсного потенціалу басейну Куяльницького лиману 3 метою сприяння розвитку рекреаційно-туристичної діяльності, враховуючи природоохоронні обмеження [25].

Багатий природно-ресурсний потенціал, рідкісні за своїми властивостями бальнеологічні ресурси (лікувальні грязі, пелоїди, мінеральні води тощо), сприятливі кліматичні умови, близькість до морського узбережжя складають унікальний природнорекреаційний комплекс Куяльницького лиману, який немає аналогів у світі. Використовуючи статистичну звітність та інтернет-ресурси офіційного сайту Одеської облдержадміністрації було проведено аналіз кількісних показників природно-ресурсного потенціалу, інфраструктурного та матеріально-технічного забезпечення рекреаційно-туристичної діяльності, а також стану екологічної ситуації адміністративних районів в басейні Куяльницького лиману [26].

На жаль, цей природний комплекс недостатньо розвинений не тільки для іноземних споживачів, але й для вітчизняних відпочиваючих. Зараз на території лиману є лише один лікувальнооздоровчий заклад - ДП «Клінічний санаторій ім. Пирогова» ПрАТ «Укрпрофоздоровниця» (далі санаторій Куяльник). Згідно медичного профілю закладу, у санаторії проходять лікування пацієнти із захворюваннями опорно-рухового апарату, нервової системи, кровоносних судин, шкірних покровів, проводять лікування жіночого безпліддя і багатьох інших захворювань.

Як свідчить статистична звітність ДП «Клінічний санаторій ім. Пирогова», кількість осіб, яким було надано лікувально-оздоровчі послуги протягом 2013-2017 років, коливається по роках. Максимального значення кількість рекреантів досягла у 2014 р. і склала 12413,0 осіб (142,0\% від попереднього періоду), що було пов'язано із відносно стабільним періодом соціально-економічного розвитку в державі та зміцненням національної валюти. У 2015 р. спостерігався різкий спад кількості відпочиваючих санаторного закладу, які отримали рекреаційні послуги, і їх величина склала лише 3464,0 (27,90\% від рівня попереднього року). Поступове зростання показників, яке спостерігається у наступних 20162017 рр., не досягло рівня 2014 року. Зараз через епідеміологічну 
ситуацію в країні та світі ускладнюється соціально-економічна діяльність цього закладу.

У грязьовому господарстві ДП «Клінічний санаторій ім. Пирогова» загалом налічується 17 басейнів для зберігання свіжої грязі. Скидання відпрацьованої грязі здійснюється транспортним трактором до басейну, де вона регенерується.

Сучасна потреба у лікувальних грязях Куяльницького курорту згідно з протоколом № 1695 засідання колегії ДЗК України по запасам корисних копалин Мінприроди України складає $1600 \mathrm{~m}^{3}$ на рік. Водночас Спеціальним дозволом Держгеонадра № 4955 від 27.03.2009 р. загальний обсяг запасів використання становить 186,5 тис. ${ }^{3}$ лікувальних грязей категорії В. На основі вищевказаного можна зробити висновок про наявність значного резерву щодо розвитку курортної та промислової діяльності стосовно використання лікувальних грязей.

Для забезпечення санаторію Куяльник поверхневою ропою працює забірна споруда розташована на технологічній дамбі (причалі). Ропа мінералопроводом діаметром 100 мм перекачується відцентровим насосом у бойлерну і далі у душові, ванні кімнати та

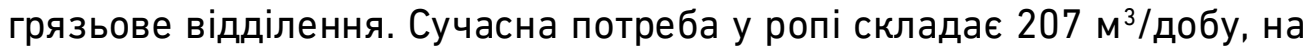
що є спеціальний дозвіл Держгеонадра № 5637 від 13.09.2012 р.

Досвід багаторічної експлуатації грязей і ропи Куяльницького родовища не має негативного впливу на довкілля за даними Протоколу № 1695 засідання колегії Державної комісії України по запасам корисних копалин Мінприроди України. В цьому ж протоколі відмічається, що існуюча схема видобутку, транспортування, переробки, використання лікувальної грязі Куяльницького родовища апробована протягом багатьох років і $\epsilon$ оптимальною для видобування та постачання курорту Куяльник та не зазнає радикальних змін.

Результати дослідження вказують на те, що територія басейну Куяльницького лиману, по-перше, $€$ унікальним природним комплексом, якому притаманні як рекреаційно-туристичні властивості, так і можливості розвитку супутніх видів діяльності, подруге, в умовах децентралізації необхідно забезпечити цілісний екологобезпечний розвиток даної території та раціональне взаємовигідне використання природних ресурсів всіма громадами, що розташовані поблизу. Ефективність та обсяги використання природних рекреаційних ресурсів безпосередньо пов'язані 3 економічними відносинами державної та недержавної форм власності на них, а також є визначними щодо можливості розвитку рекреаційного екологобезпечного бізнесу на даних територіях. 
Проведемо SWOT-аналіз передумов розвитку рекреаційної зони басейну Куяльницького лиману в контексті диверсифікації іiї природних ресурсів.

Таблиця

SWOT-аналіз передумов розвитку рекреаційної зони басейну Куяльницького лиману в контексті диверсифікації її природних ресурсів

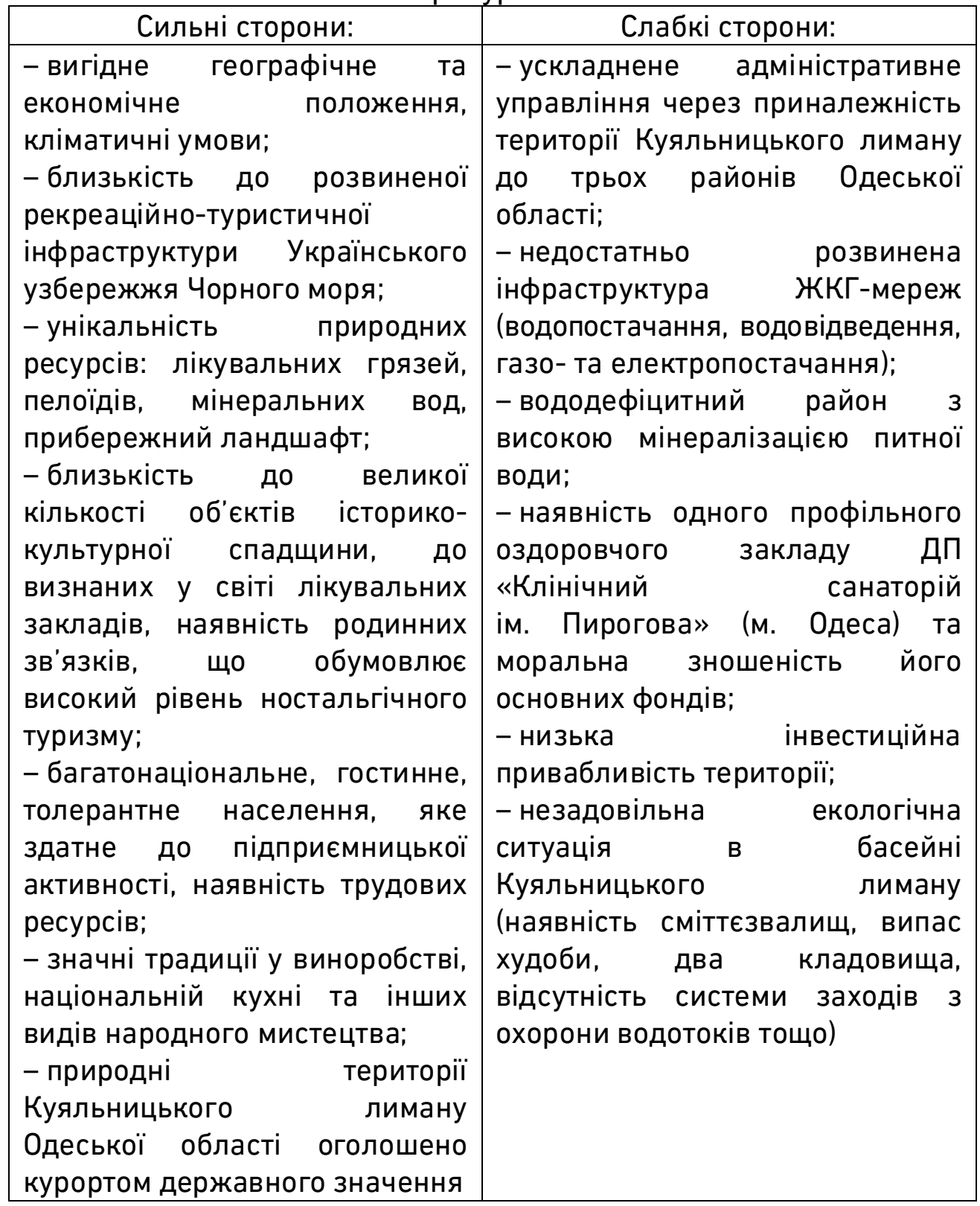


продовження таблиці

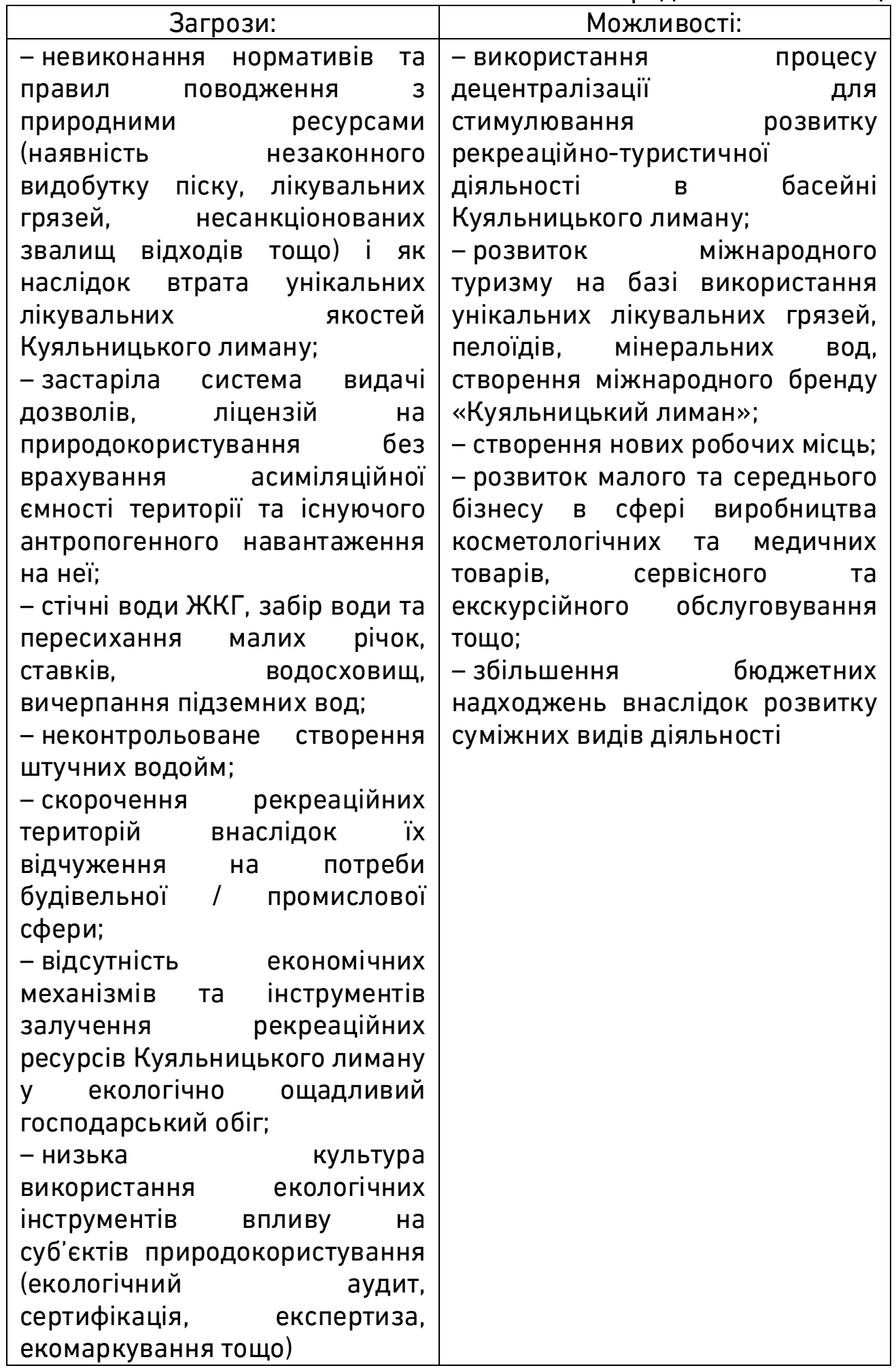

Складено за джерелом [25] 
До проблем, на розв'язання яких направлена пропонована Програма, належать:

- відсутність комплексного використання території Куяльницького лиману: природних-ресурсів рекреаційної зони, промислового та трудового потенціалу;

- обмежене використання природних рекреаційних ресурсів в оздоровчо-лікувальній та рекреаційно-туристичній сферах для виробництва більшого асортименту товарів та послуг для відпочинку, лікування та оздоровлення людей в природному середовищі з одночасним розвитком супутніх видів діяльності, що сприяють охороні та відтворенню лікувальних, оздоровчих, туристичних та інших природних ресурсів на основі інноваційної діяльності;

- неврегульованість (в умовах децентралізації) системи управління використанням природних рекреаційних ресурсів на рівні області та місцевих громад;

- проблеми соціально-економічного розвитку місцевого населення (збідніння населення, нестача робочих місць, міграційні процеси тощо);

- відсутність планування та прогнозування (стратегії) розвитку місцевих громад басейну Куяльницького лиману в напрямі рекреаційно-туристичної діяльності з визначенням: обмежень щодо відносин власності на природно-рекреаційні ресурси; умов формування сприятливого інвестиційного клімату; напрямів вдосконалення рекреаційно-туристичної інфраструктури в зоні Куяльницького лиману.

Мета Програми - комплексний соціо-економіко-екологічний розвиток території Куяльницького лиману на основі: забезпечення раціонального використання природних рекреаційних ресурсів, диверсифікації використання природних ресурсів, розвитку економічної активності місцевого населення супутніх видів діяльності в сфері рекреаційно-туристичної діяльності та екологобезпечного природокористування.

Основними завданнями Програми є:

- проведення соціо-економіко-екологічної оцінки використання рекреаційно-туристичних ресурсів суб'єктами господарського комплексу басейну Куяльницького лиману;

- ефективне використання рекреаційних природних ресурсів Куяльницького лиману на основі їх диверсифікації з акцентом на розвиток рекреаційно-туристичної діяльності;

- визначення пріоритетів розвитку системи управління рекреаційними природними ресурсами для узгодження інтересів 
області та місцевих громад, запобігання конфліктам інтересів стейкхолдерів у басейні Куяльницького лиману;

- природно-ресурсне забезпечення потреб бізнесу, населення та ОТГ поліфункціональної території басейну Куяльницького лиману;

- розробка засад стратегічного розвитку господарського комплексу басейну Куяльницького лиману на основі екологоорієнтованого використання його природних рекреаційних ресурсів у суміжних видах підприємницької діяльності.

Реалізація основних програмних заходів відбувається шляхом формування та впровадження трьох пріоритетних напрямів.

Пріоритетний напрям «Ефективне використання та збереження природних ресурсів басейну Куяльницького лиману». Заходи цього напряму спрямовані на забезпечення ефективного та раціонального використання природних ресурсів території, зокрема рекреаційнотуристичних. Основними з них $€$ адміністративні, економічні та екологічні інструменти.

Основою заходів адміністративного впливу $€$ вдосконалення дозвільної системи на використання природних ресурсів території, зокрема рекреаційно-туристичних в напрямі врахування існуючого антропогенного навантаження та асиміляційного потенціалу Куяльницького лиману. Використання інструментів сертифікації та стандартизації рекреаційно-туристичної діяльності та природних ресурсів, для забезпечення екологічної безпеки унікального природного об'єкту. Дотримання кадастрової інформації щодо рекреаційних ресурсів при прийнятті управлінських рішень розвитку території, впровадження та ведення кадастру лікувальних ресурсів. Використання переваг статусу Куяльницького лиману як курорту національного значення. Розробка та реалізація регіональних природоохоронних програм, що спрямовані на збереження унікальних природних об'єктів. Встановлення обмежень та обтяжень для суб'єктів господарювання щодо використання природних рекреаційно-туристичних ресурсів.

Основою економічних заходів є екологічна та грошова оцінка природних рекреаційних ресурсів та ефективність господарської діяльності басейну Куяльницького лиману; плата за використання природних рекреаційних ресурсів, надходження від штрафних санкція накопичуються у спеціальних природоохоронних фондах та використовуються на природоохоронні заходи. Надання податкових пільг, субсидій, субвенцій тощо стимулює розвиток підприємницької діяльності в рекреаційно-туристичній та супутніх їй сферах економіки. Реалізація заходів Програми забезпечується вітчизняними та іноземними інвестиціями. 
Серія «Економічні науки»

Випуск 4(92) 2020 р.

Екологічні заходи реалізуються шляхом впровадження комплексного інституційного механізму, що забезпечує екологобезпечний розвиток території. Він складається з таких інструментів як екологічний аудит, контролінг, експертиза, моніторинг, стратегічна екологічна оцінка, маркування, страхування тощо. До еколого-економічних важелів належать екологічні податки, збори за забруднення рекреаційних територій.

Реалізація пріоритетного напряму «Фактори сталого розвитку підприємництва в господарському комплексі басейну Куяльницького лиману» включає:

- впорядкування та інвентаризацію суб'єктів господарювання басейну Куяльницького лиману, що впливають на стан його природних ресурсів;

- розробку проєктів альтернативної господарської діяльності для розвитку підприємництва з урахуванням екологічних чинників збереження Куяльницького лиману;

- економіко-екологічні та організаційні механізми впливу на підприємницьку активність.

В основу цього напряму покладено визначення суб'єктів господарської діяльності, що впливають на екологічний стан природних ресурсів; розробка заходів спрямованих на покращення соціально-економічних показників життєдіяльності місцевого населення при одночасному ощадливому ставленні до унікальних природних ресурсів басейну Куяльницького лиману; просування сучасних методів активізації бізнесу в сфері рекреаційнотуристичної та супутніх до неї сфер економічної діяльності.

Для реалізації напряму «Розвиток рекреаційно-туристичної діяльності В зоні Куяльницького лиману» необхідно здійснити комплекс мотиваційних заходів:

1. Адміністративні: протекціоністська політика у сфері розвитку рекреаційно-туристичної діяльності, зокрема розробка регіональних цільових програм; спрощення процедур щодо розвитку малого та середнього бізнесу у сфері надання рекреаційно-туристичних послуг; сертифікація і стандартизація рекреаційно-туристичної діяльності; удосконалення відносин власності в рекреаційнотуристичному бізнесі та поширення форм державно-приватного партнерства у цій сфері.

2. Фінансово-економічні: економіко-екологічна оцінка ефективності рекреаційно-туристичної діяльності в зоні Куяльницького лиману; надання податкових пільг, субсидій, субвенцій, пільгових кредитів тощо для стимулювання підприємницької активності в екологоорієнтованій рекреаційно- 
туристичній діяльності; організаційно-економічні механізми залучення інвестицій в рекреаційно-туристичну та супутні їй сфери діяльності.

Основою фінансово-економічних заходів $€$ державна та місцева підтримка рекреаційно-туристичного підприємництва, надання податкових пільг, цільових кредитів тощо. Інвестиційна діяльність спрямовується на розвиток малого та середнього бізнесу.

3. Організаційні: популяризація рекреаційно-туристичного підприємництва; організація навчання відкриття та ведення ефективної рекреаційно-туристичної діяльності; інформаційна підтримка та просування позитивного досвіду ведення рекреаційнотуристичного бізнесу.

Організаційні заходи спрямовуються на популяризацію позитивного досвіду рекреаційно-туристичної діяльності на державному та міжнародному рівнях; впливають на просування рекреаційно-туристичного товару та допомагають малому та середньому підприємництву відкривати та вести ефективний бізнес; залучають інноваційно-інформаційні платформи: вебсайти, діджитал адвертайзмент, sms-розсилки тощо.

Для ефективної реалізації Програми пропонуємо призначити виконавцями Одеську обласну державну адміністрацію, адміністрації об'єднаних територіальних громад, місцеві органи виконавчої влади та інші організації, профільні науково-навчальні заклади, підприємства рекреаційно-туристичної сфери діяльності та інші організації та установи зацікавлені в її реалізації.

Функції постійного моніторингу реалізації заходів Програми доцільно покласти на Департамент економічної політики та стратегічного планування, Департамент екології та природних ресурсів, Управління туризму, рекреації та курортів в Одеській області та районні уповноважені органи, які відповідають напрямам заходів Програми.

Загалом, фінансування Програми може здійснюватися за рахунок місцевих та обласних бюджетів, комунальних платежів, податків і зборів та фінансів комунальних підприємств. Ключову роль відіграють фінансові ресурси (позабюджетні кошти, кошти, запозичені органами місцевого самоврядування, цінні папери) та майно місцевих органів влади та закладів комунальної власності (їх рухоме та нерухоме майно, природні ресурси і корисні копалини місцевого значення, ліси, водойми, дороги, тротуари, парки, сквери, набережні річок, річки, озера, пам'ятники архітектури та історії, заповідні території, заклади виробничої та соціальної інфраструктури, житловий фонд, підприємства, установи, 
організації), що беруть участь у формування та наданні рекреаційнотуристичних послуг.

Ефективна реалізація запропонованої Програми залежитеме від скоординованої дії інших структурних підрозділів Одеської облдержадміністрації, зокрема: фінансового департаменту, департаменту розвитку промисловості, енергетики, управління транспорту та зв'язку, департаменту містобудування та архітектури, статистики, департаменту земельних ресурсів, департаменту освіти і науки; департаменту у справах преси та інформації для координації програмних заходів, моніторингу та контролю за їх виконанням та фінансуванням.

Висновки. Використання та диверсифікація рекреаційнотуристичних ресурсів з позицій раціонального природокористування потребує забезпечення екосистемного та поліфункціонального підходів до ведення господарської діяльності. Оскільки рекреаційний природний об'єкт Куяльницький лиман є складною екологічною системою, потрібно провести зонування не тільки території, на якій він розташований, але й прилеглих до нього земель за економічними, екологічними та рекреаційними критеріями. Для екології Куяльницького лиману важливим $€$ збереження існуючих територій зелених насаджень та моніторинг стану прибережної захисної смуги, що забезпечить усталеність його екологічного каркасу, складовою якого є рекреаційні, оздоровчі, природоохоронні, водні та озеленені території.

На основі того, що програмування $€$ ефективним інструментом механізму використання природно-ресурсного потенціалу комплексних територій, нами запропоновано проєкт Програми диверсифікації використання природних ресурсів із обґрунтуванням їі структурної побудови та перспективних напрямів. Визначено мету, завдання, основні заходи, слабкі та сильні сторони, проблемні питання, запропоновані джерела фінансування, визначено соціоекономіко-екологічні результати. Таким чином, реалізація Програми диверсифікації використання природних ресурсів зони Куяльницького лиману дасть можливість отримати такі результати:

1) екологічні - визначити межі екологічного навантаження у басейні Куяльницького лиману; забезпечити диверсифікацію використання природних ресурсів для збереження екологічної рівноваги унікальних природних рекреаційних властивостей екосистеми Куяльника; попередити негативні наслідки діяльності господарського комплексу та рекреаційно-туристичного підприємництва на довкілля; вплинути на підвищення привабливості ландшафтів, збереження флори і фауни Куяльника, а також 
зменшення навантаження на них;

2) соціальні - зростання зайнятості населення, підвищення життєвого рівня населення, поліпшення умов праці та відпочинку, підвищення рівня кваліфікації та освіти населення басейну Куяльницького лиману; поліпшення забезпеченості закладами торгівлі, харчування, зв'язку, медичного та побутового обслуговування, культури, транспортними засобами тощо; зробить привабливим життя в сільській місцевості, що зупинить процес вимирання сіл, зниження рівня міграції; дасть поштовх соціальноекономічному розвитку місцевих малозабезпечених сільських громад;

3) економічні - активізація малого та середнього бізнесу на основі диверсифікації використання природних ресурсів в напрямі рекреаційно-туристичної діяльності, створення нових підприємств, задоволення попиту вітчизняних та закордонних споживачів на відпочинок і лікування, екологічно чисту продукцію харчування; зростання надходжень до бюджету за рахунок збільшення економічної активності, удосконалення та розвиток виробничої та загальної інфраструктури.

Отже, Програма диверсифікації використання природних ресурсів території Куяльницького лиману Одеської області створить передумови не тільки для сталого розвитку цієї території, але й дозволить «відкрити» унікальний курорт для світової спільноти.

1. Ансофф И. Стратегическое управление / пер. с англ. М. : Прогресс, 1999. 416 с. 2. Berry, С. H. Corporate growth and diversification. Journal of Law and Economics. 1971. № 14. С. 371-383. 3. Грант Р. М. Современный стратегический анализ / пер. с англ. ; под. ред. Н. Фунтова. СПб. : Питер, 2008. 560 с. 4. Gort M. Diversification and integration in American industry. Prinston, Prinston University Press, 1962. 233 p. 5. Кунц Р. М. Стратегия диверсификации и цели предприятия. Проблемы теории и практики управления. 1994. № 1. С. 5-8. 6. Портер М. Международная конкуренция. М. : Международные отношения, 2016. 947 с. 7. Корінько М. Д. Диверсифікація як економічний процес. Актуальні проблеми економіки. 2007. № 4 (70). С. 48-53. 8. Акмаева Р.И. Стратегический менеджмент : учеб. пособие. Астрахань : Астраханский университет, 2009. 200 с. 9. Александров С. С. Стратегия диверсификации производства как основное направление стратегического развития предприятия. Актуальні проблеми економічного та соціального розвитку виробничої сфери : матеріали міжнародної науково-теоретичної конференції молодих вчених і студентів, м. Донецьк, ДонНТУ, 22-23 квітня 2004 р. С. 75-79. 10. Бланк И. А. Основы финансового менеджмента. К. : Ника-Центр, 1999. Т. 1. 592 с. 11. Саух І.В. Класифікаційна модель та характеристика стратегій туристичних підприємств. Вісник ЖДТУ. 2017. № 4 (82). С. 90-97. DOI: https://doi.org/10.26642/jen-2017-3(81)-90-97. 12. СичЄ. М., Пилипенко 0. В. Стасишен М. С. Стратегічний аналіз : навч.-метод. посіб. К. : Каравела, 2010. 304 с. 13. Хумарова Н.І., Вартанян Г.В. Обґрунтування програми розвитку поліфункціональних територій. Економічний часопис Східноєвропейського національного університету імені Лесі Українки. 2016. № 4. С. 83-88. URL: 
http://nbuv.gov.ua/UJRN/echcenu_2016_4_16. (дата звернення: 01.10.2020). 14. Хумарова Н. І. Екологоорієнтоване стратегічне планування розвитку територій : монографія / НАН України, Ін-т пробл. ринку та екон.-екол. дослідж. 0., 2011. 408 с. 15. Нездоймінов С. Г., Андрєєва Н. М. Концептуальні засади формування стратегії диверсифікації на підприємствах туристичного бізнесу. Вісник економічної науки України. 2013. № 2 (24). С. 108-112. 16. Вартанян Г. В. Стратегії формування та реалізації туристичного потенціалу поліфункціональних територій. Економічні інновації. 2015. № 60(3). С. 41-49. 17. Милованов Е. Стратегия диверсификации основа финансовой устойчивости многопрофельного предприятия. Проблемы теории и практики управления. 2006. № 10. С. 83-85. 18. Стратегический менеджмент / под ред. Петрова А.Н. СПб. : Питер. 2005. 496 с. 19. Кудла Н. Є. Маркетинг туристичних послуг. К. : Знання. 2011. 351 с. 20. Мальська М. П., Бордун О.Ю. Організація та планування діяльності туристичних підприємств: теорія та практика. К. : Центр учбової літератури, 2012. 248 с. 21. Стеценко І. Т. Конкурентні стратегії підприємств у сфері надання послуг. Вісник ДІТБ. 2011. № 15. С. 330-335. 22. Момонт Т.В. Аналітичне забезпечення процесу диверсифікації суб'єктів туристичної індустрії. Економіка. Управління. Інновації. 2016. № 3 (18). URL: http://nbuv.gov.ua/UJRN/eui_2016_3_16. (дата звернення: 01.10.2020). 23. Кривицька Н. Ю., Громова А.С. Стратегія диверсифікації виробничогосподарської діяльності сільськогосподарських підприємств. Проблеми підвищення ефективності інфраструктури. 2011. №31. URL: http://jrnl.nau.edu.ua/index.php/PPEl/article/view/354 (дата звернення: 01.10.2020). 24. Kostetska, K., Khumarova, N., Umanska, Y., Shmygol, N., Koval, V. Institutional Qualities of Inclusive Environmental Management in Sustainable Economic Development. Management Systems in Production Engineering. 2020. 28(1). C. 15-22. 25. Popova, O., Koval, V., Mikhno, I., Tarasov, I., Asaulenko, N., Filipishyna, L. Assessments of national tourism development in terms of sustainability and inclusiveness. Journal of Geology, Geography and Geoecology. 2020. № 29 (2). C. 377386. 26. Куяльницький лиман: реалії та перспективи рекреаційного використання : монографія / Буркинський Б. В., Бабов К. Д., Нікіпелова О. М. та ін. ; Ін-т пробл. ринку та екон.-екол. дослідж. НАН України, ДУ «УкрНДІ мед. реабілітації та курортології МОЗ України». Одеса, 2019. 314 с.

\section{REFERENCES:}

1. Ansoff I. Strategicheskoe upravlenie / per. s angl. M. : Progress, 1999. 416 s. 2. Berry C. H. Corporate growth and diversification. Journal of Law and Economics. 1971. № 14. S. 371-383. 3. Grant R. M. Sovremennyiy strategicheskiy analiz / per. S angl. ; pod. red. N. Funtova. SPb. : Piter, 2008. 4. Gort M. Diversification and integration in American industry. Prinston, Prinston University Press, 1962. 233 r. 5. Kunts R. M. Strategiya diversifikatsii i tseli predpriyatiya. Problemyi teorii i praktiki upravleniya. 1994. № 1. S. 5-8. 6. Porter M. Mejdunarodnaya konkurentsiya. M. : Mejdunarodnyie otnosheniya, 2016. 947 s. 7. Korinko M. D. Dyversyfikatsiia yak ekonomichnyi protses. Aktualni problemy ekonomiky. 2007. № 4 (70). S. 48-53. 8. Akmaeva R. I. Strategicheskiy menedjment : ucheb. posobie. Astrahan : Astrahanskiy universitet, 2009. 200 s. 9. Aleksandrov S. S. Strategiya diversifikatsii proizvodstva kak osnovnoe napravlenie strategicheskogo razvitiya predpriyatiya. 10. Blank I. A. Osnovyi finansovogo menedjmenta. K. : Nika-TSentr, 1999. T. 1. 592 s. 11. Saukh I. V. Klasyfikatsiina model ta kharakterystyka stratehii turystychnykh pidpryiemstv. Visnyk ZhDTU. 2017. № 4 (82). S. 90-97. DOl: https://doi.org/10.26642/jen-2017-3(81)-90-97. 12. Sych Ye. M., Pylypenko O. V., Stasyshen M. S. Stratehichnyi analiz : navch.-metod. posib. K. : Karavela, 2010. 304 s. 13. Khumarova N. I., Vartanian H. V. Obgruntuvannia prohramy rozvytku polifunktsionalnykh terytorii. Ekonomichnyi chasopys 
Skhidnoievropeiskoho natsionalnoho universytetu imeni Lesi Ukrainky. 2016. № 4. S. 8388. URL: http://nbuv.gov.ua/UJRN/echcenu_2016_4_16. (data zvernennia: 01.10.2020). 14. Khumarova N. I. Ekolohooriientovane stratehichne planuvannia rozvytku terytorii : monohrafiia / NAN Ukrainy, In-t probl. rynku ta ekon.-ekol. doslidzh. 0., 2011. 408 c. 15. Nezdoiminov S. H., Andrieieva N. M. Kontseptualni zasady formuvannia stratehii dyversyfikatsii na pidpryiemstvakh turystychnoho biznesu. Visnyk ekonomichnoi nauky Ukrainy. 2013. № 2 (24). S. 108-112. 16. Vartanian H. V. Stratehii formuvannia ta realizatsii turystychnoho potentsialu polifunktsionalnykh terytorii. Ekonomichni innovatsii. 2015. № 60(3). C. 41-49. 17. Milovanov E. Strategiya diversifikatsii - osnova finansovoy ustoychivosti mnogoprofelnogo predpriyatiya. Problemyi teorii i praktiki upravleniya. 2006. № 10. S. 83-85. 18. Strategicheskiy menedjment / pod red. Petrova A. N. SPb. : Piter. 2005. 496 s. 19. Kudla N. Ye. Marketynh turystychnykh posluh. K. : Znannia. 2011. 351 s. 20. Malska M. P., Bordun O. Yu. Orhanizatsiia ta planuvannia diialnosti turystychnykh pidpryiemstv: teoriia ta praktyka. K. : Tsentr uchbovoi literatury, 2012. 248 s. 21. Stetsenko I. T. Konkurentni stratehii pidpryiemstv u sferi nadannia posluh. Visnyk DITB. 2011. № 15. S. 330-335. 22. Momont T. V. Analitychne zabezpechennia protsesu dyversyfikatsii subiektiv turystychnoi industrii. Ekonomika. Upravlinnia. Innovatsii. 2016. № 3 (18). URL: http://nbuv.gov.ua/UJRN/eui_2016_3_16. (data zvernennia: 01.10.2020). 23. Kryvytska N. Yu., Hromova A. S. Stratehiia dyversyfikatsii vyrobnycho-hospodarskoi diialnosti silskohospodarskykh pidpryiemstv. Problemy pidvyshchennia efektyvnosti infrastruktury. 2011. № 31. URL: http://jrnl.nau.edu.ua/index.php/PPEl/article/view/354 (data zvernennia: 01.10.2020). 24. Kostetska, K., Khumarova, N., Umanska, Y., Shmygol, N., Koval, V. Institutional Qualities of Inclusive Environmental Management in Sustainable Economic Development. Management Systems in Production Engineering. 2020. 28(1). C. 15-22. 25. Popova, O., Koval, V., Mikhno, I., Tarasov, I., Asaulenko, N., Filipishyna, L. Assessments of national tourism development in terms of sustainability and inclusiveness. Journal of Geology, Geography and Geoecology. 2020. № 29 (2). S. 377386. 26. Kuialnytskyi lyman: realii ta perspektyvy rekreatsiinoho vykorystannia : monohrafiia / Burkynskyi B. V., Babov K. D., Nikipelova O. M. ta in. ; In-t probl. rynku ta ekon.-ekol. doslidzh. NAN Ukrainy, DU «UkrNDI med. reabilitatsii ta kurortolohii MOZ Ukrainy». Odesa, 2019. 314 c.

Golikova O. S. [1; ORCID ID: 0000-0001-7301-2430], Junior Research Fellow Economic regulation of Nature Use Department

\footnotetext{
${ }^{1}$ Institute of market problems and Economic-Ecological Research of NAS of Ukraine, Odesa, Ukraine
}
PROGRAM APPROACH TO THE ISSUE OF DIVERSIFICATION OF THE NATURAL RESOURCES USE IN THE RECREATIONAL AND TOURIST SPHERE

The article identifies the prerequisites for the implementation of the strategy of diversification of the use of natural resources in the recreational and tourist sphere. The state and characteristics of the socio-economic situation of the recreational object are analyzed on the example of the territories of the Kuyalnytskyi estuary basin. According to the results of the analysis it is found that there is a rich natural resource potential, rare 
balneological resources, favorable climatic and geographical conditions, which together create a unique natural and recreational complex of Kuyalnitskyi estuary, the closest analogue to the quality of therapeutic mud and brine is the Dead Sea. The dynamics of economic and current operational indicators of the enterprise of the recreational sphere is analyzed on the example of SE «Clinical Sanatorium named after Pirogov» of Private joint stock company «Ukrprofozdorovnytsia». Based on the results of the analyzed reporting of the sanatorium on the use of balneological resources, in particular therapeutic mud, peloids and brine, it can be concluded that they have a significant reserve for the development of recreational and tourist sphere. The SWOT-analysis in the context of natural resources use diversification of the territories of the Kuyalnitskyi estuary basin is carried out. A number of problematic issues have been identified, for the solution of which the draft Program is proposed. The project of the Program of realization of natural resources use diversification is presented, the Program purpose and structure is formed, the basic actions is given. The main tasks include socio-economic and environmental assessment of the natural resources use, effective use of recreational resources of the Kuyalnytskyi estuary in the context of its diversification, prioritization of recreational natural resources management system, natural resource provision of stakeholders of the Kuyalnytskyi estuary basin and development of economic complex. The priority directions of the Program and their components are revealed, the mechanisms of realization of priority directions are given. Sources of financing of the Program, executors and responsible ones for the function of constant monitoring of the program activities implementation are offered.

Keywords: diversification program; natural resources; recreational and tourist sphere; diversification strategy implementation program.

Голикова О. С. [1; ORCID ID: 0000-0001-7301-2430], М.н.с. отдела экономического регулирования природопользования

${ }^{1}$ Институт проблем рынка и экономико-экологических исследований НАН Украины, Одесса, Украина

\section{ПРОГРАММНЫЙ ПОДХОД К ВОПРОСУ ДИВЕРСИФИКАЦИИ ИСПОЛЬЗОВАНИЯ ПРИРОДНЫХ РЕСУРСОВ В РЕКРЕАЦИОННО- ТУРИСТИЧЕСКОЙ СФЕРЕ}

В статье определены предпосылки реализации стратегии диверсификации использования природных ресурсов в рекреационнотуристической сфере. Проанализировано состояние и характеристики социо-экономической ситуации рекреационного объекта на примере территорий бассейна Куяльницкого лимана. По результатам анализа 
установлено, что имеется богатый природно-ресурсный потенциал, редкие по свойствам бальнеологические ресурсы, благоприятные климатические и географические условия, которые вместе создают уникальный природно-рекреационный комплекс Куяльницкого лимана, ближайшим аналогом к качеству лечебных грязей и рапы является Мертвое море. Проанализирована динамика экономических и имеющихся эксплуатационных показателей предприятия рекреационной сферы на примере ДП «Клинический санаторий им. Пирогова» ЧАО «Укрпрофздравница». По результатам проанализированной отчетности санатория по использованию бальнеологических ресурсов, в частности лечебной грязи, пелоидов и рапы, можно сделать вывод о значительном их резерв для развития рекреационно-туристической сферы. Проведен SWOT-анализ в контексте диверсификации использования природных ресурсов территорий бассейна Куяльницкого лимана. Выделен ряд проблемных вопросов, по-для решения которых предлагается проект Программы. Приведен проект Программы реализации диверсификации использования природных ресурсов, сформирован цель, предоставлено структуру, основные мероприятия. К основным задачам отнесены проведения социо-экономико-экологической оценки использования природных ресурсов, эффективное использование рекреационных ресурсов Куяльницкого лимана в контексте их диверсификации, определения приоритетов развития системы управления рекреационными природными ресурсами, природно-ресурсное обеспечение потребностей стейкхолдеров бассейна Куяльницкого лимана и разработка основ стратегического развития его хозяйственного комплекса. Раскрыто приоритетные направления Программы и их составляющие, предоставлено механизмы реализации приоритених направлений. Предложено источники финансирования Программы, исполнителей и ответственных за функцию постоянного мониторинга за выполнением программных мероприятий.

Ключевые слова: программа диверсификации; природные ресурсы; рекреационно-туристическая сфера; программа реализации стратегии диверсификации. 